\title{
伝統的建造物群保存地区の建蔽率と容積率に関する考察 \\ 一奈良県橿原市今井町地区を中心としてー \\ A STUDY OF THE FAR AND BCR IN THE PRESERVATION DISTRICTS \\ FOR GROUPS OF HISTORIC BUILDINGS
}

- Case study at Imai-cho district, Kashihara city, Nara prefecture, Japan -

\author{
メンドサ島田 オルガ恵子* \\ Olga Keiko MENDOZA SHIMADA
}

\begin{abstract}
The system of preservation district for groups of historic buildings is important for preserving the cultural values of historic cities. In order to promote the conservation of these values, this paper analyses the Floor Area Ratio (FAR) and Building Core Ratio (BCR) in each block and lot of Imai cho preservation district. As conclusion, it is important to know the relation of the FAR and BCR with the historic buildings in 3 terms: historical architectural function, plot plan structure, and historic development of the urban structure. Both indicators help to understand the historic development of Imai-cho, and may be used as an important tool for the conservation of urban historic area.
\end{abstract}

Keywords: Preservation district for groups of historic buildings, Imai-cho, FAR, BCR 伝統的建造物群保存地区、今井町、建蔽率、容積率

\section{はじめに}

伝統的建造物群保存地区（以下、伝建地区）における、建蔽率と 容積率については、これまで、岐阜県高山市等を事例に未利用容積 と開発権の移転や成長管理等が論じられている ${ }^{11}$ 。また奈良県橿原 市今井町伝建地区（以下、今井町地区）については建築基準法緩和 条例との関連で、法定建蔽率 60\%を超える実態から $80 \%$ に緩和した

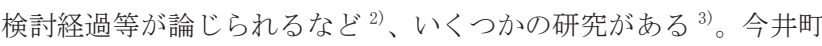
地区は、1978-81 年度の建設省文化庁調査 ${ }^{4)}$ 、1991 年度橿原市調査 (以下、1991 年度調查 $)^{5)}$ 等、比較的多くの資料や研究がある ${ }^{6)}$ 。 特に 1991 年度調查は、調查時点での今井町地区の全戸の敷地面積、 建築面積、延面積等について詳細なデータがあり、本論文の根幹を な寸資料である。

本研究は、まず今井町地区についての上記の既存資料と、1991 年度調査資料と対照して 2006-07 年に筆者が行った、空地や新築等 の悉皆的な現地調查結果と比較し、変化を検討する。次に、歴史的 町並夕を分析し理解する方法としての建蔽率と容積率を考察し、さ らに今後の町並み景観を誘導する保存計画との関連で、建蔽率と容 積率の有効性を考察するものである。

なお、今井町は 1993 年に都市計画決定により伝建地区の指定を受 け、地区内は第 1 種中高層住居専用地域として、法定建蔽率 $60 \%$ 、 同容積率 200\%となっている。同じ 1993 年制定の「橿原市今井町伝 統的建造物群保存地区における建築基準法の制限の緩和に関する条 例」第 5 条 $^{7)}$ によれば、伝統的建造物（以下、伝建物） ${ }^{8)}$ でこの建蔽 率制限を越えているものについては、その既存の範囲内で超過を認 め、修景では建蔽率 $80 \%$ まで認める ${ }^{9)}$ な゙゙措置をとっている。

\section{1. 今井町地区の地区及び街区としての建蔽率と容積率 1-1 地区の変化と街区の多様性}

今井町地区は 1993 年に重要伝建地区に選定され、環濠に囲まれた
ひとつの完結した伝統的都市の全体 17. 4ha が保護対象となってい る。他の全国の伝建地区の多くが都市の一部分であるのとは異なり、 今井町地区では都市全体の建築的な構成が読み取れるところが特徴 である。伝建地区の景観としては、2006 年の写真 (写 1-1、1-5、写 真位置は表 1-2 に示寸) でわかるように、典型的な「つし二階町屋」 と「長屋」 ${ }^{10)}$ の町並みが美しい姿をよく残す一方で、15 年前の調査 よりも建物が減って空地（写 1-2、図 1-2 の空地）や駐車場が 4 倍 近く増加している（表 1-1）。地区の外側に接する部分などでは、 新築 3 階建等の歴史的景観に不調和な建物（写 1-3、1-4、2-3）が 増えつつある。また社会的には、今井町では人口の 6 割前後が借家 や長屋等に居住し ${ }^{11)}$ 、老齢化・空家化・空地化が進行している ${ }^{12)}$ 、 とされている。一方で、地区周囲の景観も大きく変化しつつあり、 かつては環濠の外側に一面の田畑が広がっていたのが、大阪への通 勤が可能な住宅地として、地区外東側の駅寄りの商業地域指定区域 や新たにできた環状道路北側の第 1 種住居地域に、 6 階建中層マン ション等の建設が進んでいる ${ }^{13)}$ 。

\section{1-2 街区単位で見た建蔽率の分布構成と変化への対応}

このような都市の構成とその変化を地区全体として検討するため、 図 1-1 では、1991 年の全戸調查資料 ${ }^{5)}$ に基づき、地区の全 52 街区 について当時の建蔽率と容積率をグラフで示した。道路面積を除く 全街区 15.25ha の平均の建蔽率は 56.4\%、容積率は $74.6 \%$ あるるが、 これを同資料に基づき図 $1-2^{14)}$ のように、建蔽率を 6 段階に区分し て地図を作成すると、都市全体としては決して均質な分布ではない ことが判明する。地区全体としては、中心部の町並み景観保存状態 の良い街区で高い建蔽率となるのに対して、周辺街区では当時でも 60\%以下の低い建蔽率とその後の空地の増加が目立つ。また、通勤に 便利な駅に近い東寄りの街区では、中心部の街区と匹敵する $70 \%$ 前 後の高い建蔽率となっていることがわかる。近代の鉄道開通以後の 東寄り街区での高密度化を差し引いて復原的に考えると、寺内町と 


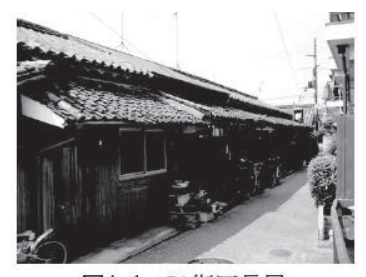

写1-1 Bi街区長屋

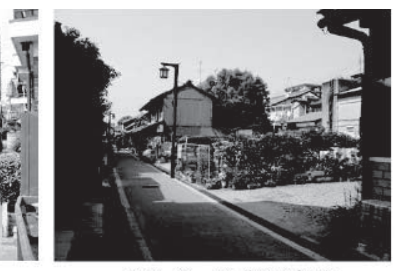

写1-2 Gk街区空地

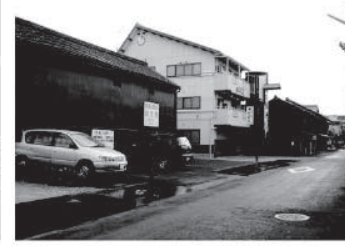

写1-3 Hi街区 3 階建新筑

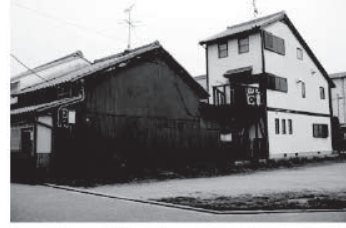

写1-4 Bg街区 3 階建別棟 ·空地

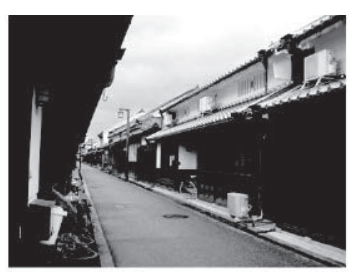

写1-5 Cg Dg街区町屋

$120 \%$

$60 \%$ $30 \%$

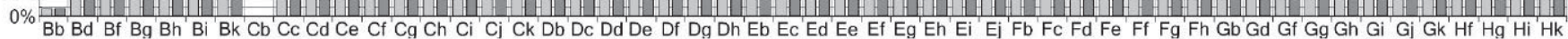
図1-1 今井町地区 0 街区別建蔽率・容積率 (道路面積除く全面積 $15.25 \mathrm{ha}$ 、全体街区建蔽率: $56.4 \%$ 容積率: $74.6 \%$ 、1991年5) ) 建蔽率 $\square$ 容積率 $\square$

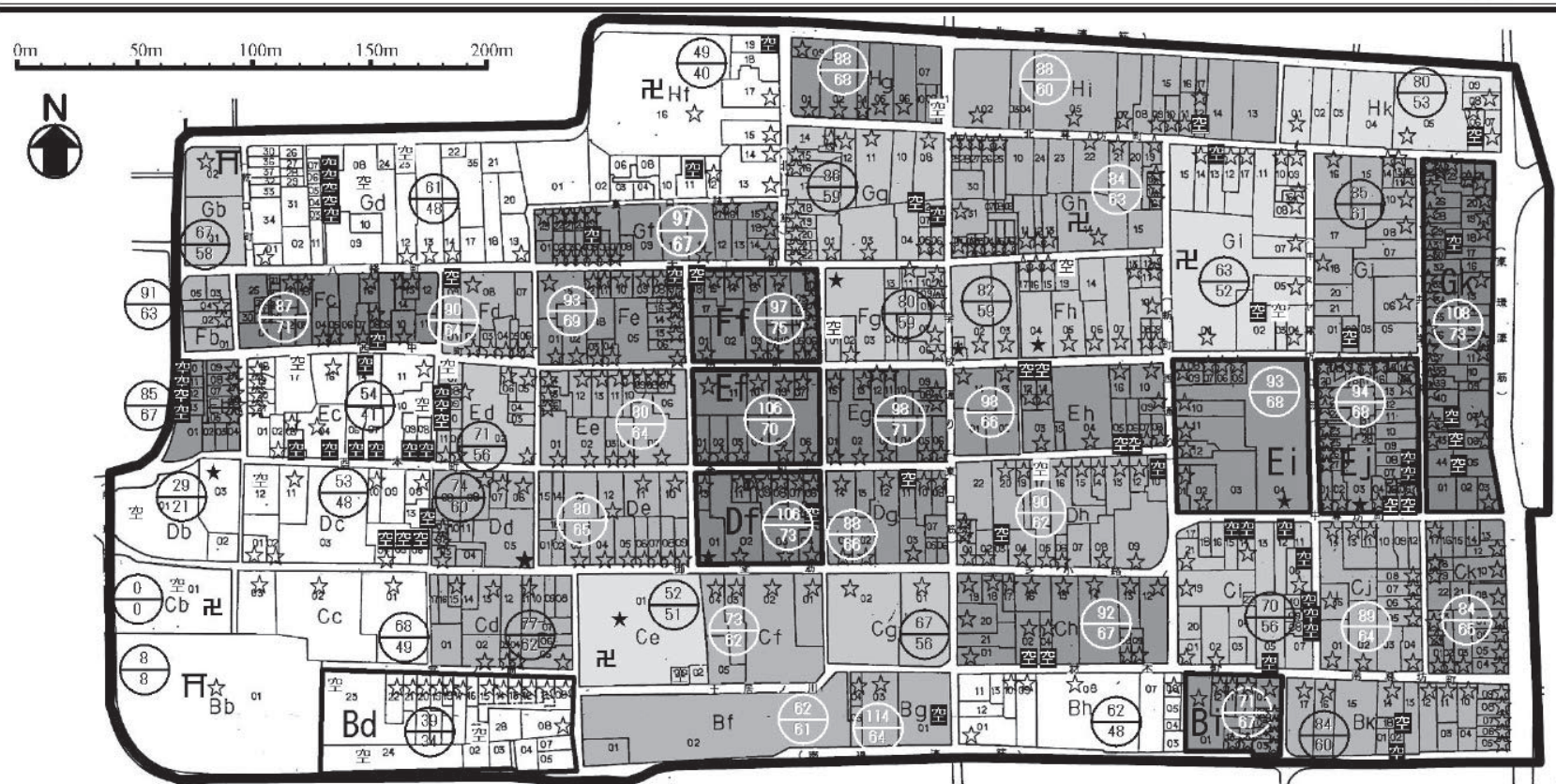

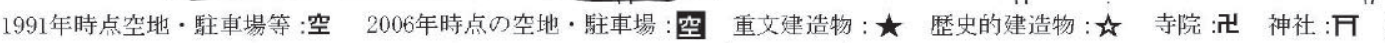
重要伝統的垏造物群保存地区 面積 : $17.4 \mathrm{~h}$

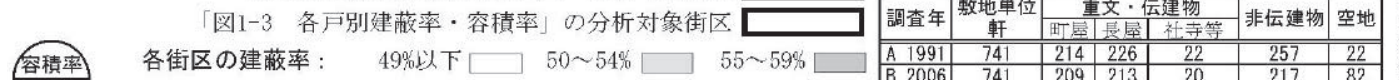

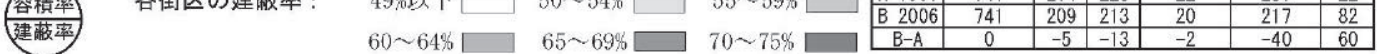

図1-2 今井町地区の街区別の建蔽率・容積率分布地図 (1991年4) 5) 表1-1 15年間の敷地利用の変化 表1-2 街区ブロック記号司

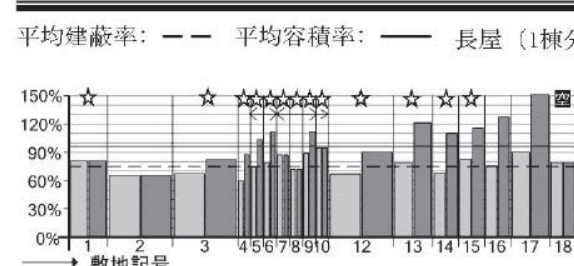

図1-3-1 Ff 街区 $\left(2070 \mathrm{~m}^{2}\right)$

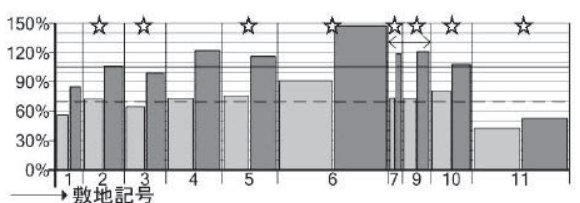

図1-3-2 Ef街区 $\left(2103 \mathrm{~m}^{2}\right)$

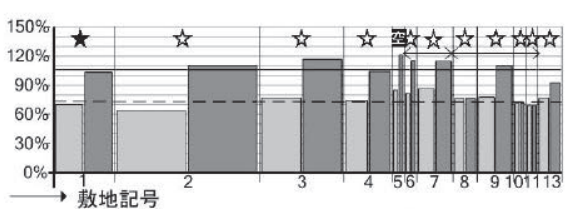

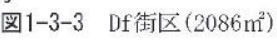

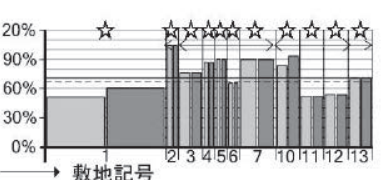

図1-3-4 Bi街区 $\left(1340 \mathrm{~m}^{2}\right)$

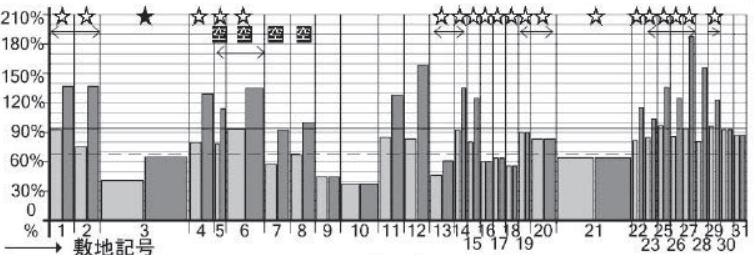

図1-3-5 Ej街区 $\left(2852 \mathrm{~m}^{2}\right)$

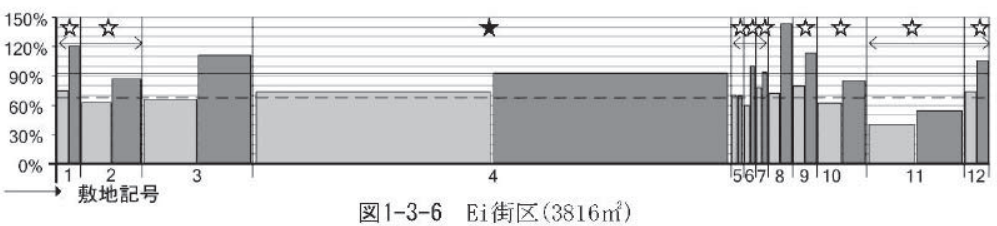

図1-3-6 Ei街区 $\left(3816 \mathrm{~m}^{2}\right)$

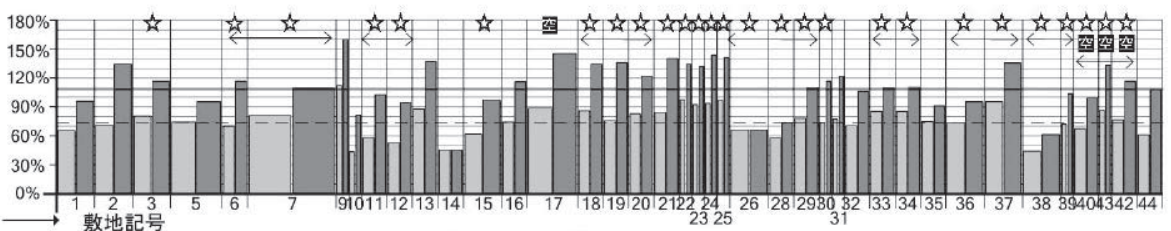

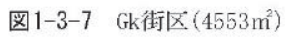

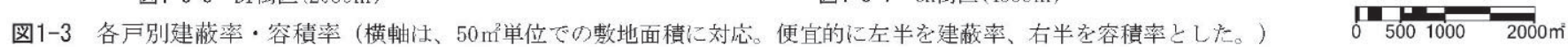


しての今井の全体の骨格は、伝統的には中心部の背割溝のある密度 の高い都市的な街区を、周辺の密度の低い街区が囲むような構成を 持っていた。環涼に面したり近い街区では背割溝がなくて、星印で 示寸各家の入口は町の中心方向に向いており、濠に背を向けた長屋 などからなっていたことが、想定される。現状でも、この中心部に は大きな敷地の町屋が多い街区（町屋街区）、周辺部には小さな敷 地の長屋が多い街区（長屋街区）が多い。そして、2006 年時点調査 で増加した空地の多くは、1991 年調査で歴史的建造物と評価された 長屋が壊されて生まれたこと、また長屋の多い周辺街区で空地が主 に増えていることから、この 15 年間での変化を大きく受けたのは主 として周辺の街区であると考えられる。

\section{1-3 町屋の多い街区と長屋の多い街区}

図 1-2 の基礎となった 1991 年調査資料では、建築基準法緩和の対 象となるべき伝建物候補として、原則として昭和 20 年以前に建設さ れた全ての町屋と長屋を、敷地単位の軒であげている。これは、そ の後 1993 年に所有者の同意を得て告示をした現行の伝建物棟数と はやや異なるが、91 年時点での実情を正確に知ることができる歴史 的価值の高い情報と考えられ、本図ではこれを歴史的建造物として 星印で入口位置を表示し、各戸の建蔽率や容積率の分析は、この調 查資料を対象として行っている。図 1-2 は、街区としての平均的な 建蔽率を表示しているが、各街区の中の構成は、町屋や長屋の各戸 について、その建蔽率と容積率を見る必要がある。歴史的建造物が 多く、空地がほとんど無くて高い建蔽率を維持している街区は、伝 統的な町並みの保存状態がよいところであるが、ここでは、中心部 分から Df、Ef、Ffの 3 街区、東寄りの周辺部分から Ei、Ej、Gkの 3 街区、そして長屋が多いBi 街区の、計 7 街区を選んで、1 軒ごと の建蔽率と容積率をグラフで示したのが図 1-3 である。グラフの横 幅は敷地面積に対応しており、各戸は敷地の広さにおいて町屋と長 屋では大きな相違があり、長屋は 1 棟分ごとに間口方向の幅を示し ているが、 1 軒ずつの敷地が極めて小さく均質という特徴がある。

\section{1-4 街区としての建蔽率と容積率}

この 7 街区のうち、地区中心部にある Df、Ef、Ff 街区は、建蔽率 70-75\%、容積率 97-106\%の範囲にあり、特に高い Df 街区 (73\%・106\%) は各戸の率にばらつきが少なく、つし二階町屋を中心に景観的な密 度が高い。一方、地区の東寄り周辺部にある $\mathrm{E} i 、 \mathrm{Ej} 、 \mathrm{Gk}$ 街区は、建 蔽率 68-73\%、容積率 93-108\%で、中心部と同じくらい高いが、狭い 敷地で 2 階建長屋が多く、増築等による容積率のばらつきがあって 150\%近いものも多い。南寄りの周辺部にある Bi 街区（写 1-1）は、 今も平屋の長屋がまとまって美しく残るところで、建蔽率 $67 \%$ に対 して容積率は $71 \%$ と低い。

\section{2. 今井町地区の建物種別の建蔽率と容積率 2-1 町屋街区の主屋と別棟}

上記の分析で典型的なつし 2 階町屋の並ぶ Df 街区は、寺内町今井 の草創期から存在した街区で、中心となる称念寺に近く（写 2-1）、 重要文化財中橋家住宅など質の高い町屋の町並みが現存する（写 2-2）。その連続平面図と連続立面図（図 2-1-1）6)のからは、街区 が中心にある東西方向の背割線で南北に 2 分され、各戸は道路に面 する主屋と、裏側の中庭を隔てての隠居座敷や土蔵などの別棟に分 かれ、御堂筋（写 1-5）などの表通りの町並み景観は主屋の外観が
担っていることがわかる。主屋と別棟の各々の建蔽率・容積率 ${ }^{15)}$ を算出すると、図 2-1-2 のグラフになる。図の 02 敷地に見られる背 割線を越えての増築等からは、保存上変更が困難な主屋に替わって 奥の別棟が新しい変化の受け㿼となる状況がうかがえ、一方で長屋 （ここでは本来の町屋を分割居住したもの）では、図 2-1-2 の 06、 10、11 敷地のように、別棟が極めて小さい傾向にある。つまり、表 通りから見えにくい奥の別棟区域で重大な変化が進行している。

\section{2-2＼cjkstart敷地と建築の面積から見た町屋と長屋}

町屋と長屋の相違は、敷地面積と建築面積の面からみると性格が はっきりする。図 2-3 は、歴史的建造物である町屋と長屋・それ以 外の新しい非伝統的建造物（以下、非伝建物）の 3 種類について、 敷地面積と建築面積の軒数をそれぞれ 3 段階に分けて分析したもの である。長屋は敷地 $100 \mathrm{~m}^{2}$ 以下建築 $80 \mathrm{~m}^{2}$ 以下のものが最多となる。 町屋は各段階に広く分布するが、敷地 $200 \mathrm{~m}^{2}$ 以上建築 $80 \mathrm{~m}^{2} \sim 240 \mathrm{~m}^{2}$ が最多となる。非伝建物は、その両者の傾向があるが、数としては 長屋に近い方が多い傾向がある。

\section{2-3建物種類別に見た建蔽率と容積率}

上記のような、歴史的建造物である町屋と長屋・非伝建物では、 それぞれの主屋と別棟の構成はどうなっているだろうか。保存地区 の価値を担保寸る町屋・長屋の全歴史的建造物 440 軒と、非伝建物 257 軒について、主屋と別棟の建蔽率・容積率の全体的な構成を示 したのが、図 2-4 である。町屋・長屋の平均的な建蔽率は、法定建 蔽率 $60 \%$ を越えているが、高い方の長屋でも $70 \%$ 程度までであって 緩和建蔽率の $80 \%$ より低い。また、平均的な容積率は、高い長屋で も 90\%程度で、法定容積率の 200\%よりはるかに低い。これに対して 新しい社会的な要求を反映すると考えられる非伝建物では、全体に 歴史的建造物よりも建蔽率・容積率ともにやや高くなる傾向がある が、容積率でも $100 \%$ には達していない。そして、主屋に対する別 棟の割合は、町屋や大きい非伝建物において、建蔽率・容積率とも に高い傾向が見える。

\section{2-4＼cjkstart町屋と長屋からみる主屋と別棟の構成の伝統}

歴史的建造物での主屋と別棟の関係をより明確にするために、町 屋・長屋に分けて建蔽率・容積率の視点から見たのが、図 2-2 と図 2-5 である。まず、図 2-2 はX 軸を容積率、Y 軸を建蔽率として、凡 例のような 4 種類の建物が全街区でどう分布するかを示している。 容積率が建蔽率の 1.0 ～1.8 倍程度の範囲に収まるのは自然である が、4 種類の建物がそれぞれの異なる群を形成しており、町屋と長 屋の群の組み合わせがはっきり異なることがわかる。すなわち、町 屋街区は Df 街区のように、主屋と別棟が近接した建蔽率・容積率の 群で組み合わされるのに対して、長屋街区は Gk 街区のように、遠く 隔たった建蔽率・容積率の群で組み合わされている傾向が判明する。 これは、長屋では、狭い敷地面積いっぱいに主屋を建てるため、別 棟としては小さな便所くらいしか建てられないが、広い敷地の町屋 ではゆったりと隠居座敷や土蔵を主屋に近いくらいの大きさで建て ることができたことを示している。図 2-5 は、このような町屋と長 屋の明確な相違が頻度分布からも言えること、また、非伝建物でも 同じように主屋と別棟という 2 種類の建物から構成されていること を示している。写 3-1の事例は、長屋とは違う町屋を実現するため には大きな別棟が必要という規範が、平入り屋根の形態規範より強 い場合もあり得ることを示している。 


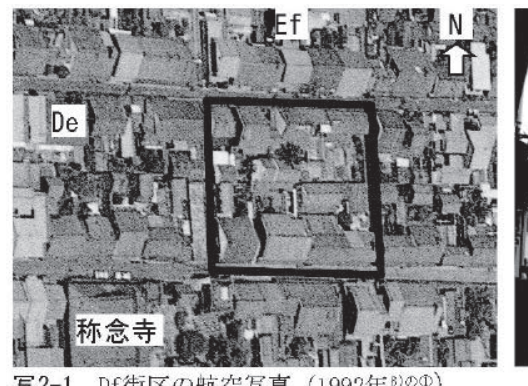

写2-1 Df街区の航空写真 (1992年B)の)

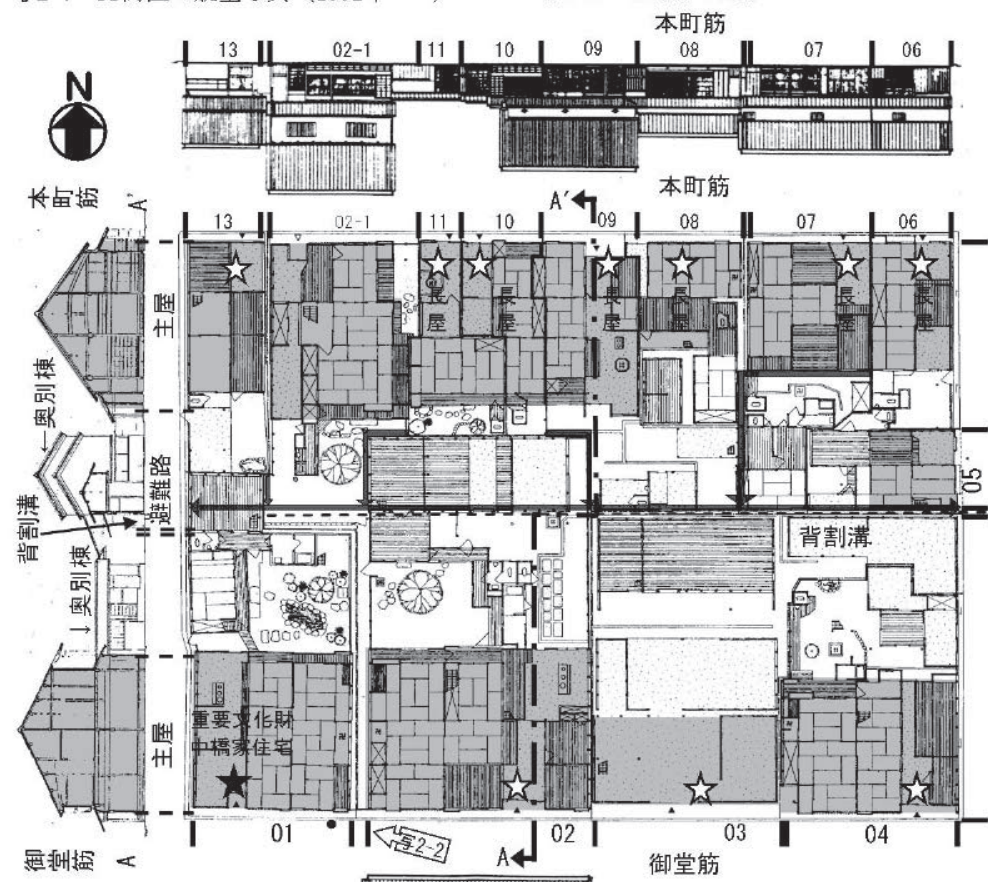

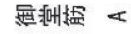

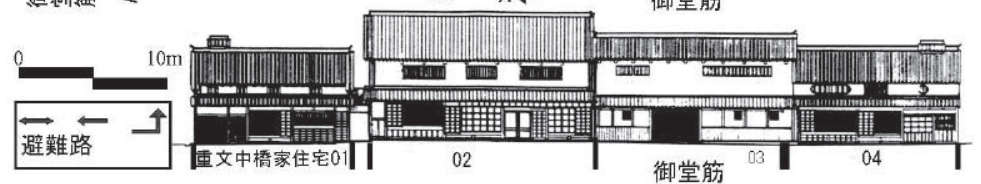

図2-1-1 Df街区連続平面図(1981年4)、8)の0)

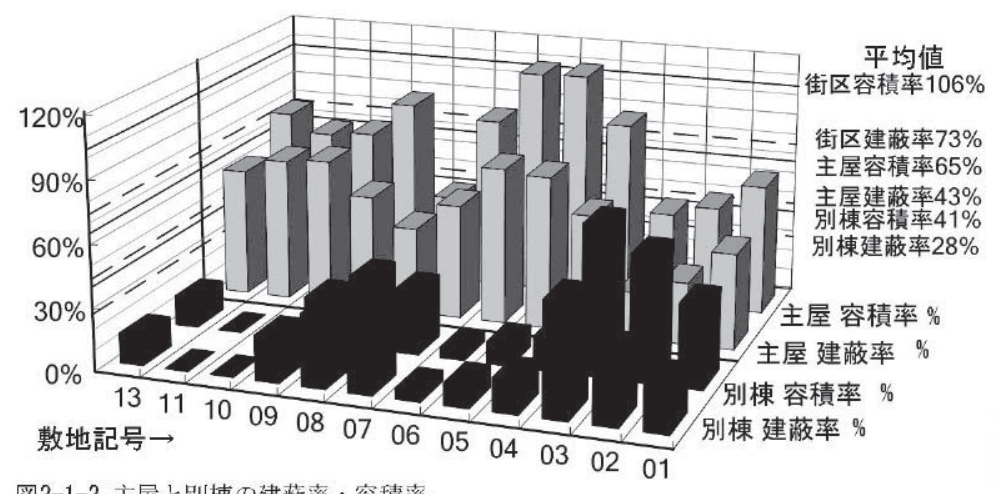

図2-1-2 主屋と別棟の建蔽率・容積率

図2-1 Df街区の主屋亡别棟の敷地利用状況

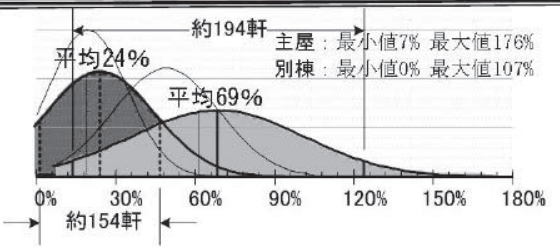

図2-5-1 歴史的建造物の町屋 (全214軒)

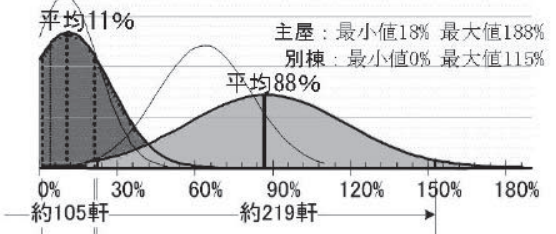

図2-5-2 歴史的狡造物の長屋 (全226軒)

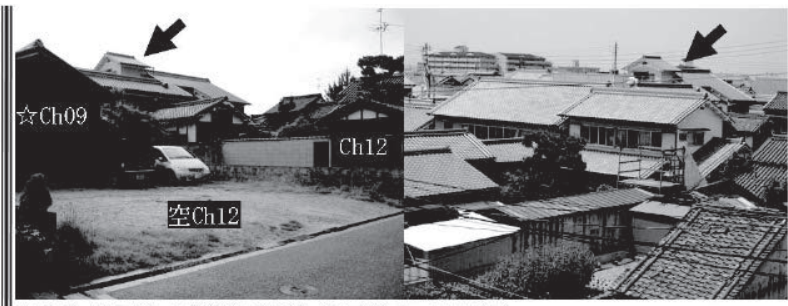

写2-3 地区内の新築 3 階侓（Ch街区、2007年）

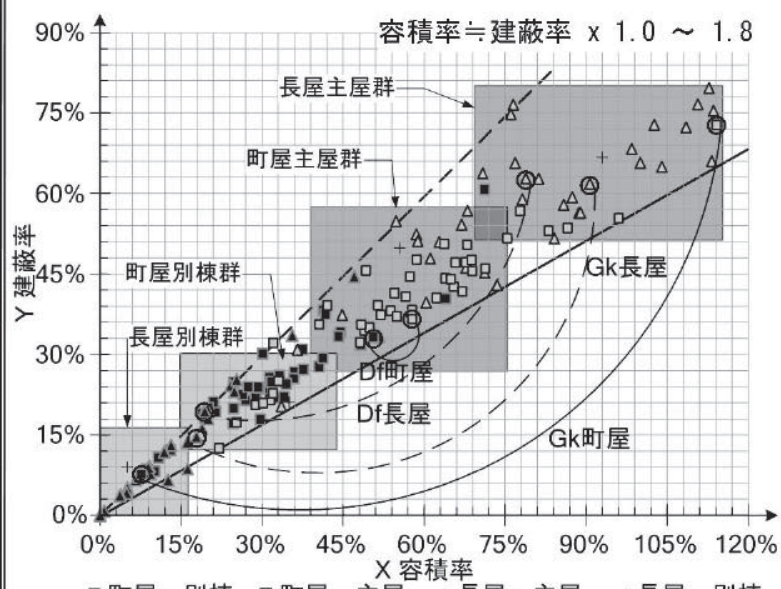

- 町屋 - 別棟 口町屋 - 主屋 $\Delta$ 長屋 - 主屋 $\Delta$ 長屋 - 別棟

図2-2 主屋·別棟の建蔽率・容積率 (歴史的建造物のみ)

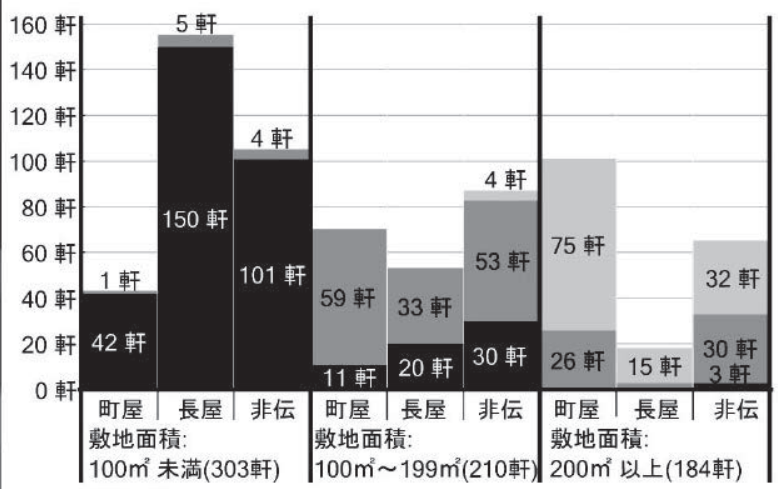

建築面積： $80 \mathrm{~m}^{2}$ 未満 $80 \mathrm{~m}^{2} \sim 239 \mathrm{~m}^{2} \quad 240 \mathrm{~m}^{2}$ 以上

358軒 213 126 軒

図2-3 建造物種別の敷地面積と建築面積

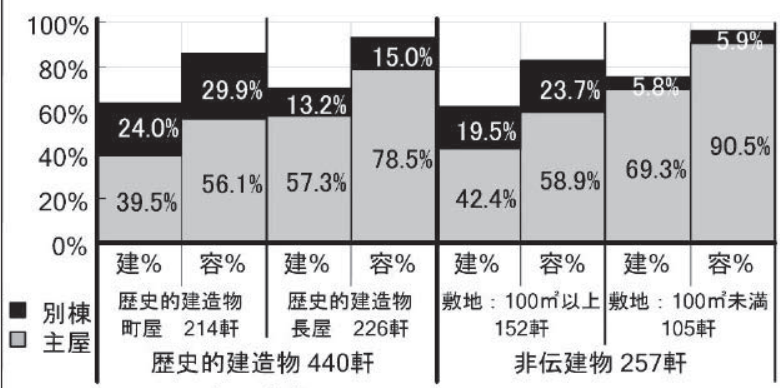

図2-4 主屋・別棟 $の$ 建蔽率 - 容積率 (町层·長屋・非伝建物全体)

図2-5 全街区の歴史的建造物（長屋、町屋）及び非伝建物の建蔽率・容積率の頻度分布（別棟容積率 $\square$ 主屋容積率 $\square$ 建蔽率 $\square ）$

図2 奈良県橿原市今井町重要伝建地区の建物種別の建蔽率・容積率の現況（1981年4)、6)の、1991年5) 
3. 伝建地区の保存計画と建蔽率・容積率

\section{3-1 社会的規範としての建蔽率・容積率}

このような敷地利用と建物構成に関する一定の明確な規範が明治 以降も伝統的に存在し、戦後の新しい建物でもその規範が継承され ているのであれば、今後のまちづくりにおいてもそれは継承可能で あり、また今井町という都市全体の構成を保存しょうとする場合に は、その規範保持は伝建地区の保存計画上の重要な事項となるはず である。町並み景観を構成する主屋外観を保存する一方で、少なく も町屋の場合には別棟で近代化への要請に応えることで保存が容易 になるはずであり、その範囲を建蔽率・容積率の形で明確に示すこ とが望まれる。その必要性は、写 2-3 の新築建物の写真を見ると、 極めて急がれる事態であることがわかる。すなわち、ここでは町屋 街区の内側で別棟が大きく膨張し、さらに 3 階望楼を造ってスカイ ラインを破るような自己主張をする新しい傾向が始まっている。 3-2 建物高さの規範と建蔽率・容積率の連携

町並み景観を保存する重要な規範のひとつは建物高さであり、今 井町地区では都市計画により周辺地域も含め高度地区 $10 \mathrm{~m}$ が設定さ れている。寺内町の中心である称念寺本堂などを別にして、民家で の最高の高さは図 3-2 のように最古の重要文化財今西家住宅主屋の
棟高さ $10 \mathrm{~m}^{16)}$ であり、他の重要文化財民家はこれに及ばない。図 3-3 は、主屋裏側に建つ別棟は、前面道路から望見される可能性は低い ことを示す。しかし、自動車駐車場などの空地が広がると、写 $2-3$ のように道路から望見される可能性が高まる。また、周辺部の街区 で 3 階建を建てる場合には、写 1-3，1-4 のように、容易に不調和な 姿が旧環濠沿いの通りから見えることになる。最近では、写 3-2 の ような 3 階建も散見される。これらの対策としては、高さ制限だけ では不十分で、これと組み合わせて、伝統的な範囲での建蔽率・容 積率の制限の設定をすることが、必要となろう。

\section{3-3 他の伝建地区の建蔽率 · 容積率との比較}

今井町地区での伝統的街区としての最高の建蔽率・容積率は、Df 街区ではそれぞれ 73\%・106\%、Gk 街区で 73\%・108\%であるが、他 の伝建地区ではどうであろうか。関西の近代の町並みである京都市 産寧坂地区石塀小路（大正初期）の典型的街区例の建蔽率 64\%・容 積率 $107 \%$ 、また関東での土蔵造町並みである埼玉県川越市川越地 区（明治末期）の典型的な屋敷構成の建蔽率 64\% ・容積率 116\%の事 例を、図 $4^{17)}$ で示した。これら近代の総 2 階建の町並みと比較する と、江戸時代以来のつし 2 階町屋が多い今井町地区は容積率では低 いはずなのであるが、近代の地区と比べ建蔽率は約 $10 \%$ 高く、容積

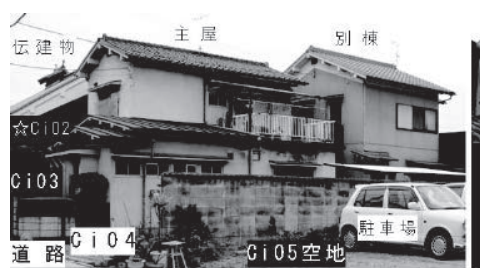

写3-1 Ci街区03

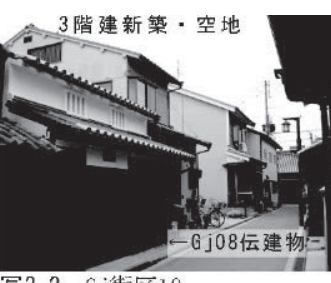

図3-1 伝統と異なる新築 $の$ 事例
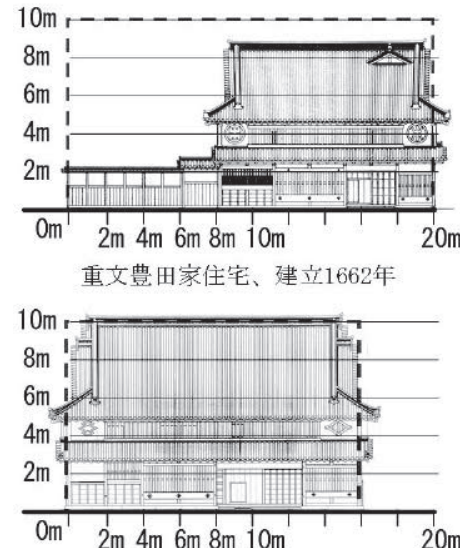

重文今西家住宅、建立1650年

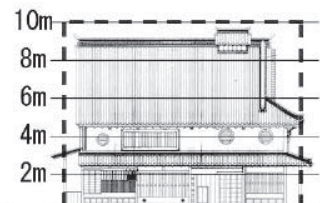

$0 m$ Om $2 m 4 m 6 m 8 m 10 m \quad 14 m$ 重文旧河合家住宅、建立18世和

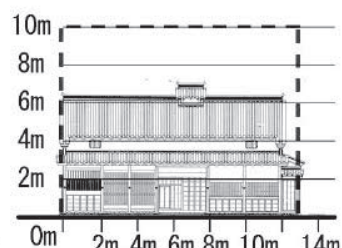
重文旧米谷家住宅、建立 18 世紀 図3-2 重要文化財民家の主屋と $10 \mathrm{~m}$ 高さ制限

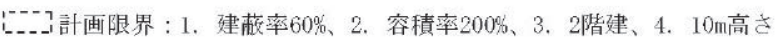

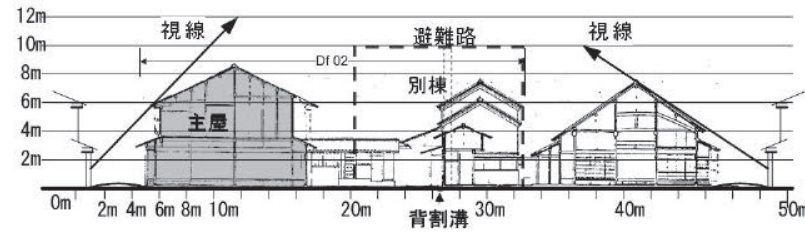

現状:Df街区02、主屋 : 建蔽率 $30 \%$ 容積率 $50 \%$ 、別棟 : 建蔽率 $34 \%$ \%容積率 $60 \%$ 図3-3 町屋街区の別棟新増築の限界

図3 今井町重要伝建地区 $\sigma$ 保存計画上の課題 ${ }^{\theta} \sigma(1)$
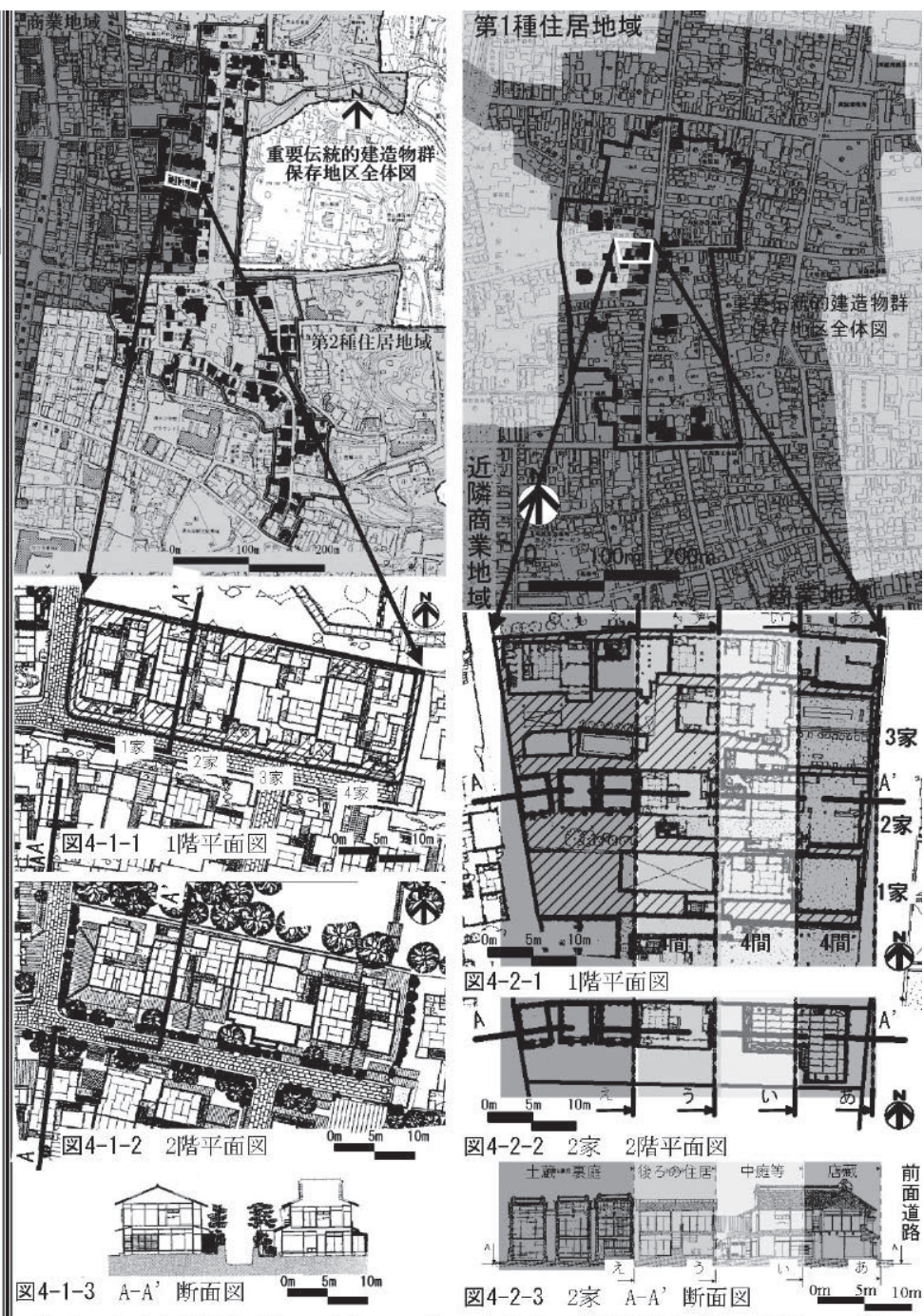

図4-1 産寧坂地区（建64\%容107\%）図4-2 川越地区（建64\%容116\%） 図4 他の重要伝建地区の建蔽率 · 容積率との比較 ${ }^{17}$ 
率は近い值となっており、今井町の都市としての密度の高さが表れ ていると見ることができよう。そして、伝建地区の建蔽率・容積率 が、時代や類型が違ってもこのように一定の範囲内であることは、 その保存計画上もっと重視されるべき事実であろう。

\section{3-4 都市計画と保存計画の建蔽率・容積率}

一方、これら 3 地区の都市計画の用途地域による法定の建蔽率・ 容積率は、それぞれ、60\%・200\%、80\%・400\%、80\%・400\%とな っており、特にその容積率が歴史的な地区としての保存に適合しな いものであることは明らかである。たしかに、重要伝建地区の規制 は、文化財保護法に基づく伝建地区保存条例で担保されており、地 区内部では現状変更規制により、伝建物の維持や新築修景への規制 がなされている。しかし、都市計画法の中に位置づけられ、周囲の 歴史的風致と一体をなして保存する伝建地区の本来の制度からは、 周囲の隣接地域が高層化されるなかでの保存を余儀なくされている ことの矛盾は、大きい。伝建地区とその周囲の景観が密接に関係し ていることは、地区内部から周囲の高層ビルが見えること、地区に アクセス寸るときに景観的に発見が困難な状況などからも、明らか である ${ }^{13)}$ 。文化遺産の、都市の中での適切なあり方に関する新しい 制度が、必要であろう。伝建地区の歴史的な蓄積の結果としての現 況の容積率と都市計画の法定値の乘離は、その矛盾の直接的な表現 とも言えるものであり、今後の伝建保存対策調查等において、その 把握が必要となっている。

\section{4. まとめ}

寺内町という歴史的な都市の全域を伝建地区とする今井町地区に ついて、歴史的に形成された建蔽率・容積率を、個々の建築のレベ ルをこえて、地区・街区、また町屋・長屋や主屋・別棟という建築 種別のグループとして把握し、相互の関係を分析した。この結果、 以下のようなことが判明した。

1 ）今井町地区全体の街区単位での建蔽率の分布構成によれば、町 屋の多い中心街区や東の駅寄りの街区が 60-70\%と高いのに対 して、周辺街区では $60 \%$ 以下が多い。つまり、寺内町今井は、 中心部の密度の高い町屋街区を周辺の密度の低い長屋街区が囲 む、同心円的な都市の構成であったと想定される。

2 ) 町屋と長屋では、主屋と別棟の構成内容で明確な相違がある。 伝統的な建蔽率・容積率の分析から、町屋は大きな間口一杯に 2 階建の主屋を建てて主屋背後の敷地に大きな別棟（隠居離れ や土蔵等）をもち、街区の中心で街区を南北に分ける背割溝ま で高密度に利用する敷地利用方法が共通し、一方の長屋では狭 い敷地で背後には便所等の最低限の別棟を持つ敷地構成だった ことが把握できる。

3) 近年の社会的変化による開発は、町屋街区での別棟区域の高密 化、周辺街区を中心とする空地の増加、3 階建の新築などとし て現れている。今井町地区のように都市全体の構造が残ること が評価された伝建地区において、歴史的な価值、伝統的な価值 を伝えるためには、表通りの主屋の外観を残寸だけでなく、地 区全体として、街区・区域・敷地単位の、現在まで存在してき た敷地利用形態をできるだけ尊重する必要がある。その保存計 画の誘導方法の一つとして、歴史的に形成された建蔽率・容積 率を基礎としたガイドラインを設定し、他の高さ規制や建築位
置規制などとも組み合わせて、運用することも必要である。

4 ）地区や街区としての建蔽率・容積率の分析は、敷地の形態や建 築の技術的な構造や用途を越えて、抽象化した数字で比較でき る点に特色がある。近代の埼玉県川越地区と京都市産寧坂地区 がほぼ同じ率であること、これと比較して江戸時代以来の町屋 が多く残る今井町地区の密度の高さが判明するなど、今後の歴 史的地区の分析手法として重要と考えられる。

5 ) 現行の都市計画の用途地域による法定の建蔽率・容積率は、伝 建地区の歴史的な建蔽率・容積率と数值上で大きな乘離がある。 伝建地区が都市計画法の地域地区のひとつであること、周囲の 歴史的風致と一体をなして保存されるべき制度であることから、 都市計画における地区保存のための改善措置が必要と思われる。

注

1）山本明、吉野智彦：「伝統的建造物群保存地区における成長管理一未利用容 積からみた保存地区類型の把握と高山市三町における容積制御試案一」、 日本都市計画学会学術論文集、第 32 回、62 号、pp. 367 372、1997 年。

2）藤崎浩治：「歴史的町並み保全と建築規制に関寸る研究-橿原市今井町伝統 的建造物群保存地区における建築基淮法の緩和措置の検討を通じて一」、 日本都市計画学会学術論文集、第 29 回、92 号、pp. $547 \sim 552 、 1994$ 年。

3）宮城俊作：「歴史的市街地における敷地単位の空間構成と『にわ』の存在形 態」、日本造園学会、造園雑誌 53 (4) 、 pp. 250 263、1990 年。

4）「橿原市今井町伝統的建造物群調査報告書、歴史的環境保全市街地整備計画 調查報告書IV 一八幡町地区、南尊坊地区及び全地区調查及び要約一」、橿原 市、1981 年; 「橿原市今井町伝統的建造物群調査報告書、歴史的環境保全 市街地整備計画調查報告書III 一 北尊坊地区、共栄町地区一」、橿原市、1980 年; 「歴史的環境保全市街地整備計画調査報告書、昭和 53 年度国土総合開 発事業調整費」、文化庁、1979 年; 「歴史的環境保全市街地整備計画調查 報告書、昭和 52 年度国土総合開発事業調整費」、建設省、1978 年。

5）「橿原市今井町伝統的建造物群保存予定地区における建築基隻法の緩和条 例案の検討調查報告書」、橿原市・（株）都市環境研究所、1991 年。

6) 次の資料、研究等：(1) 渡辺定夫編者「今井の町並引」、同朋社出版、1994 年 ; (2) 林清三郎「今井の建物 II」、今井町町並み保存会、2005 年 ; (3) 林 清三郎「今井の建物」、今井町町並多保存会、2000 年; (4) 八甫谷邦明編 者「迫生る自治都市『今井』」、今井町町並み保存会、2006 年 ; (5) 岡崎篤 行、原島幸彦：「歴史的町並みを生かしたまちづくりにおける合意形成過程 に関する事例一橿原市今井町地区の伝建地区指定を対象として一」、日本都 市計画学会学術論文集、第 29 回、92 号、pp. 547 552、1994 年。

7）「今井町緩和条例第 5 条」伝統的建造物について建築等をする場合において 建築等を行ったときの伝統的建造物の建蔽率割合が、施行日における当該伝 統的建造物の建蔽率割合を超えず、かつ、市長が交通上、安全上、防火上及 び衛生上支障がないと認めて許可したものについては、法第 53 条の規定は 適用しない。

8）文化財保護法施行令では、伝建地区においては、伝統的形態を維持している ものを「伝統的建造物」として特定して保護することとなっている。

9）同条例第 7 条 2 項や同条例取扱要綱では、修景基淮に適合する新筑は敷地が 100 平方メートル以下の場合は市長は条例の審査基準により、交通上安全上 防火上等で支障がないと認める為の条件をつけることができるとしている。

10）5）の定義、つし 2 階は「伝統的町家に多く見られ本 2 階に比べて 2 階の階高 が低いもの」、長屋は「柱等の主要構造物を共有しているもの」による。

11) 八甫谷邦明編者「延る自治都市『今井』」(今井町町並み保存会、 p. 160 、 2006 年) には、「今井町では、人口の 6 割前後が借地借家」とある。

12）佐野雄二、岡崎篤行、高見沢邦夫：「橿原市今井伝建地区における長屋の利 用形態と景観の実態」日本都市計画学会学術論文集、第 33 回、106 号、pp. 631 〜 631、1998 年。

13）メンドサ島田オルガ恵子:「伝統的建造物群保存地区と周辺の景観保存方法」 日本建築学会学術講演梗概集、pp. 263 264、2006 年。

14）図 1-2 の街区の記号は 1981 年代の調査以来、表 1-2 街区ブロック記号のよ うに割付けられている。なお、1991 年調査報告書では 742 軒の敷地とする が、 1 軒 (Cd 街区 14 敷地番号) だけ情報が脱落しているため、本論文では 741 軒で計算している。

15）建蔽率と容積率は通常、敷地面積と敷地内建物から算出されるが、本論文で は歴史的都市における敷地内の伝統的な建籊群の構成を詳細に考察するた め、便宜的に通りに面した主屋と敷地後方の別棟に分け、各々の建蔽率と容 積率を算出した。

16）「重要文化財今西家住宅修理工事報告書」、奈良県教育委員会、1962 年。

17）メンドサ島田オルガ恵子：「国内事例 - 3 ; 埼玉県・川越市川越地区重要伝 統的建造物群保存地区」、「東アジアにおける歴史的集落空間の保存手法に 関する研究科学研究費補助金研究成果報告書 (研究代表者益田兼房) 」 . p. 57 、 2007 年 ; 「石塀小路町並夕調查報告書」、京都市都市計画局、1994 年。 